\title{
Empirical Investigation of Five-Factor Model of Personality ${ }^{1}$
}

\author{
Fahrudin JS Pareke ${ }^{*}$ and Rina Suthia Hayu ${ }^{2}$ \\ ${ }^{1,2}$ University of Bengkulu, Bengkulu, Indonesia
}

\begin{abstract}
The concept of Five-Factor Model (FFM) of Personality describes the basic dimension of human behavior, thinking, and emotions that related to the job. The FFM currently getting popular and reach more attention to from the scholars and practitioners as well, particularly in the area of human resource management. Therefore, the main goal of current research is to compile and to test the dimensions of FFM and its measure empirically. Eighty-four self report measures distributed to the 238 employees who work both for public and private organizations at the Northern Sumatera Island, Indonesia. The respondents are currently completing their graduate programs at the University of Bengkulu. Twohundred-and-eighteen questionnaires completed and returned by respondents, and analyzed using Factor Analysis with Varimax Approach to extract them in to the several components. Based on the analyses, research confirmed the 5 dimensions for FFM, which is conscientiousness (18 items), extraversion-introversion (18 items), agreeableness (12 items), openness to experience (14 items), and emotional stability (12 items). The result strictly recommended that the use of FFP as a means of Human Resource Practices such as selection, promotion, training, and the like.
\end{abstract}

Keywords: Agreeableness, Conscientiousness, Emotional Stability, Extraversion, Openness to Experiences, Personality

\section{INTRODUCTION}

Personality refers to the way someone reacts and interacts with others (Robbins and Judge, 2009: 139). Personality is defined as the patterns of behavior, thought, and unique emotion and relatively stable which is shown by someone (Greenberg and Baron, 2009: 97). Mount (2005) concluded that personality refers to traits of characteristics that are stable over time, the reason underlying the one's behavior. Personality reflects the owner and generally determine one's affective style, behavioral, and cognitive.

Definition specifically states that personality is the patterns of thought, emotions, and behaviors that are relatively stable and unchanged for certain period of time and explain human behavior in different situations (Elanain, 2007). Personality differeces between individuals explain someone gives different responses with others in the same situation. Personality differences also explain

\footnotetext{
* Corresponding author. Email address: pareke@uni.ac.id

${ }^{1}$ Earlier version of the manuscript has been presented in Malaysia Indonesia International Conference on Economics, Management, and Accounting, November 10th to 11th, 2014. Kuala Lumpur, Malaysia.
} 
why someone tends to show a certain behavior for a particular situation, while others show a different behavior for the same situation.

Basically, classify individuals in a certain personality group is very difficult. Because it is hardly find 2 individuals who have identical thoughts, emotions, and behaviors, even 2 twin siblings. But experts in the field of organizational behavior has made great efforts to formulate a personality pattern that is able to gather a few people of a certain personality group. Associated with it, has appeared various conceptualizations of personality that is quite popular, such as the big 5 of personality (Costa and McCrae, 1992), possitive and negative affective (Isen and Baron, 1992), type A and type B behavior (Friedman and Rosenman, 1974), and morning-evening person (Guthrie et al., 1995).

Among various personality conceptualizations above, the most popular and get a lot of attention from practitioners, academics, and researchers are personality conceptualization of the big 5 of personality (Five-Factor Model/ FFM). This concept has been widely accepted as a complete picture of the nature of personality (Saucier and Ostedorf, 1999). In accordance with the table, this concept assumes that one's personality can be measured for each of five different dimensions, namely Conscientiousness, Extraversion-Introversion, Agreeableness, Emotional Stability, and Openness to Experience.

Conscientiousness dimension describes the extend how far someone is hardworking, neat, self-contained, and diligent versus lazy, frivolous, and not reliable. Extraversion-Introversion dimension describes how far someone who likes to make friends, assertive, and tolerant versus loner, shy, and reserved. Agreeableness shows how far someone is cooperative, warm, easy to fit versus quarrelsome, cold and not easily matched. Emotional Stability shows how far someone is someone who is anxious, worried, and depressed versus feel safe, calm and happy. And Openness to Experience dimension describes how far someone is someone who is creative, curious, and cultured versus practical and has little interest range.

1. Extraversion relates to the degree how far someone is outgoing and active individual physically and verbally. Individuals who have high score of extraversion dimension is individual who like adventure, frank, sociable, assertive and like to talk. Individuals who have low score on this dimension are generally reclusive and look more reserved, shy, cautious, and dislike to socialize. Individuals who have an average score for this dimension like mix situation between associate and aloof (Weaven et.al.,2009).

2. Agreeableness refers to the altruistic nature, guardian, care, and emotional support. Consequently, someone who has a high score of this dimension is characterized by the nature of the good-natured, friendly, sympathetic, warm, and like to give. Otherwise, the low individual score of agreeableness are individuals who like to compete, hostile, indifferent, selfish, vengeful, and jealous (Weaven et al., 2009).

3. Conscientiousness relates to the degree how far someone always set high standards, have a good job, and show goal oriented behavior. Conscientiousness is very strongly associated with achievement and a desire 
to achieve it. An individual who has high score of this dimension is described as someone who concentrates on very limited number of goals, which is tried seriously. This type of individual is obedient, orderly, competent, responsible and conscientious. Otherwise, individuals who have low score of this dimension are people who are easily confused, and impulsivity (Weaven et al., 2009).

4. Emotional Stability refers to the degree how far someone is associated with stress. Individuals who have high score of this dimension generally is quiet and relaxing person, and very rarely have a mental or physical pressure that is associated with stress. Individuals who have low score of this dimension generally is a less stable, tend to feel fear, worry, easily influenced, and tend to be fear, depression, mental disorders due to the effect of stress (Weaven et al., 2009).

5. Openness to experience is degree how far someone opened to new ideas, interested in the culture/civilization and creative. Individuals who have high score of this dimension is generally interested in the experiences which related with sensory and cognitive, like anything new, can grow in complicated situations, and very liberal. Individuals who have low score of this dimension are people who are conventional, conservative, show interested in kinship, and dislike the changes (Weaven et al., 2009).

Research in the field of personality shows an important role of FFM dimensions in predicting one's performance (Salgado, 1997; Judge et al., 1998). Salgado (1997) concluded that individuals with high scores of conscientiousness and emotional stability dimension has high performance for all types and aspects or the work. As for other dimensions of FFM, relevant only to certain types of work (Judge et al., 1998). Gill and Hodgkinson (2007) noted that the concept of FFM has been so widely used in the practice of selection and assessment. Dimensions of FFM implicated as predictors of career success for various types of work, starting from sales force and customer service up to managerial positions and roles of other semi-killed.

FFM, as noted by Salekin et al.,(2005), considered to have gained empirical support in terms of convergent and discriminant validity either self-assessment, peer, or partner. However according to Gill and Hodgkinson (2007), measurement techniques that have been used freely in field have many deficiencies. Thus become an important task of empirical research to formulate and provide easier empirical evidence to be adopted for the importance of practice in the field.

\section{METHODS}

Data collection in this research were divided in three groups of respondents, consisted of experts group, employee group, and samples. Each of the respondents group use different method and data collection technique, according to the type of data and data collection purposes. The data came from a team of experts will be collected be the method of in-depth interviews. These data collection method is used for digging sharper and detailed information about aspects or personality traits. With in-depth interview technique is expected can be identified personality 
traits of an employee in accordance with the conceptualization. FGD is used to confirm the data of personality traits which are netted through in-depth interviews, so obtained the measurement items that can then be tested through survey methods, namely the questionnaire. The number of participants was 12 people, consisting of private employees and civil servents working in various institutions in Bengkulu.

The research sample for the survey was 234 civil servents and private employees in various cities in Bengkulu and surronding areas. The sample frame was the students who were studying in graduate programs in the Faculty of Economics and Business in University of Bengkulu, namely Master of Management, Master of Development Planning, and Master of Accounting. Samples were taken randomly, proportional to the number of students in each of graduate program. Data collection instrument was a questionnaire which consisted of 84 items of question. Questionnaires were given directly to the respondents. Of 234 questionnaires distributed, only 218 respondents who fill out completely and return to the researcher. Of the 218 respondents who participated in this research, $63 \%$ were male and $69 \%$ of respondents worked in government agencies. In term of age, $54.59 \%$ of respondents aged less than 26 to 35 years old. Based on the period of employment, $62.39 \%$ of respondents had worked for their current organization in the span of less than 10 years. $68.55 \%$ of the respondents were employess of public agency, and $49.54 \%$ were staff or not having the structural position in the organization where they worked.

Analysis technique is the triangulation analysis, combining qualitative and quantitative technique. Qualitative technique is used to analyze the data from the results of depth-interviews and FGD. Qualitative analysis is conducted to identify the indicators and measurement items FFM constructs. Qualitative analysis uses an interactive model approach developed by Milles and Hubberman (1992:20). Four stages of analysis interact with each other to form a cycle of analysis, which consists of data collection, data presentation, data filtering, and inference data. Quantitative analysis is applied by using analysis factor with the help of an application program, that is Statistical Product and Service Solutions (SPSS). Analysis factor helps reduce the number of variables (items) very much (all the questions that form the desired variables in a questionnaire) to be a series of significant factors, can be interpreted, and handled. Principal component analysis is applied to transform all items into a series of variables group that are not correlated with each other (Sekaran, 2000: 409). Linear combination of these variables are called factors, which calculates the variance contained in the data as a whole. The best combination to form the first principal component is the first factor. The second principal component is defined as a linear combination of the best variable to explain unaccounted variance through the first factor, and continued to the third factor, the fourth, and so on (Cooper and Schindler, 2001: 594).

\section{RESULTS}

The results of factor analysis of 84 items of FFM question with Varimax rotation method, producing 5 factors or components with loading factor score was 
more than 0.4. As shown in table 1, the first factor has 18 items of question, the second factor also has 18 items of question, the third factor has 12 items of question, the fourth factor has 14 items of question, and the fifth factor has 12 items of question.

Table 1 The Number of Explained Data Variance

\begin{tabular}{clccc}
\hline No. & Factor & $\begin{array}{c}\text { Number of } \\
\text { Eligible Items }\end{array}$ & $\begin{array}{c}\text { \% Explained } \\
\text { Variance }\end{array}$ & $\begin{array}{c}\text { Explained } \\
\text { Variance } \\
\text { Cumulative }\end{array}$ \\
\hline 1. & First & 18 & 10.471 & 10.471 \\
2. & Second & 18 & 10.067 & 20.538 \\
3. & Third & 12 & 8.176 & 28.714 \\
4. & Fourth & 14 & 6.964 & 35.677 \\
5. & Fifth & 12 & 6.801 & 42.479 \\
\hline
\end{tabular}

These factors or components of FFM were able to explain $42 \%$ of the total of data variance. The first factor is a collection of items that ask personal type characterized by the indicators: diligent, organized, neat, well-planned, thorough, passionate, reliable, responsible, and cautious. In accordance with the identification of theoretical that is proposed by the authors and previous researchers (Ferguson, 2004; Burke and Witt, 2004; Gill and Hodgkinson, 2007; Salgado, 1997; Judge et al., 1998; Judge and Erez, 2007; Furnham et al., 2005), this factor is called conscientiousness dimension. This factor was able to explain $10.47 \%$ of the data variance.

The second factor is a collection of items that ask personal type characterized by the indicators: adaptive, likes to be the center of attention, talkactive, sociable, friendly, smart break the ice, cheerleaders, open, and assertive. In accordance with the definition of theoretical that is proposed by the authors and previous researchers (Judge and Erez, 2007; Gill and Hodgkinson, 2007; Salgado, 1997; Judge et al., 1998; Furnham et al., 2005), this factor is named Extraversion-Introversion dimension. This factor was able to explain $10.7 \%$ of the data variance.

The third factor consists of items that ask personal type characterized by the indicators: what it is, care, sensitive, tolerant, positive thinking, forgiving, seldom complain, and make friends easily. In accordance with the definition of theoretical that is proposed by the authors and previous researchers (Juhasz et al., 2009; Burke and Witt, 2004; Weaven et al., 2009; Judge and Erez, 2007; Furnham et al., 2005), this factor is named Agreeableness dimension name. This factor was able to explain $8.18 \%$ of the data variance.

The fourth factor consists of items asking personal type characterized by the indicators: like abstract ideas, imaginative, complex, rich vocabulary, often using difficult words, like trying new things, like art, always curious, and willing to take risks. In accordance with the definition of theoretical that is proposed by the authors and previous researchers (Weaven et al., 2009; Gill and Hodgkinson, 2007; Salgado, 1997; Judge et al., 1998; Judge and Erez, 2007; Furnham et al., 2005), this factor is named Openness to Experience dimension. This factor was able to explain $6.80 \%$ of the data variance.

The fifth factor consists of items that ask personal type characterized by the indicators: relaxed, calm, able to control the feeling, feeling happy, rational, 
patient, and feel safe. In accordance with the definition of theoretical that is proposed by the authors and previous researchers (Marcus et al., 2007; Ferguson, 2004; Weaven et al., 2009; Gill and Hodgkinson, 2007; Judge and Erez, 2007), this factor was named Emotional Stability dimension. This factor is able to explain $6.80 \%$ of data variance.

\section{Conscientiousness Dimension}

Based on the results shown in table 2, 18 items of question that are expected to form conscientiousness dimension has loading factor $\geq .400$. Nine items that use reverse score (reverse score symbolized by the mark ${ }^{\circledR}$ ) also has good loading factor, which the value is more than .400 . The items of question that were given reverse score reflect the personality type that is reverse from the main concept.

Table 2 Loading Factor Value of Conscientiousness Dimension (Rotated Component Matrix)

\begin{tabular}{|c|c|c|c|c|c|c|}
\hline \multirow[t]{2}{*}{ No. } & \multirow[t]{2}{*}{ Statements } & \multicolumn{5}{|c|}{ Component } \\
\hline & & 1 & 2 & 3 & 4 & 5 \\
\hline 1. & I always pursue what I am doing & .545 & & & & \\
\hline 2. & I am the type of regularly person & .480 & & & & \\
\hline 3. & I am the type of neat individual & 615 & & & & \\
\hline 4. & I have a good plan for every thing & 641 & & & & \\
\hline 5. & I am a careful person & 694 & & & & \\
\hline 6. & $\begin{array}{l}\text { I am always enthusiastic in doing every } \\
\text { activities }\end{array}$ & .705 & & & & \\
\hline 7. & I always reliable for a lot of things & .592 & & & & \\
\hline 8. & $\begin{array}{l}\text { I am the type of responsible individual for } \\
\text { what I do }\end{array}$ & 682 & & & & \\
\hline 9. & I am always careful in every my jobs & .499 & & & & \\
\hline 10. & $\begin{array}{l}\text { I would rather give up and do other things } \\
\text { when faced with difficulties }\end{array}$ & .467 & & & & \\
\hline 11. & I am the type of person who tends to fall apart & 694 & & & & \\
\hline 12. & $\begin{array}{l}\text { I prefer to finish my job before the time than } \\
\text { spend the time to make it more presentable }\end{array}$ & 638 & & & & \\
\hline 13. & $\begin{array}{l}\text { I am the type of person who flows (not bound } \\
\text { plan) }\end{array}$ & 668 & & & & \\
\hline 14. & I tend to be reckless in doing my job & 620 & & & & \\
\hline 15. & I am the type of lazy person & .720 & & & & \\
\hline 16. & I am not person who can be relied & .616 & & & & \\
\hline 17. & $\begin{array}{l}\text { Better I avoid or grant mistakes to others than } \\
\text { sacrificing my self }\end{array}$ & 668 & & & & \\
\hline 18. & I have felt to neglect many things in my life & .528 & & & & \\
\hline
\end{tabular}

\section{Extraversion-Introversion Dimension}

As shown in table 3,18 items of question were estimated to form the Extraversion-Intraversion dimension has loading factor $\geq .400 .9$ items of question that use reverse score (reverse score symbolized by the mark $®$ ) also has good loading factor, which the value is more than .400 . The items of question that were given reverse score reflect the personality type that is reverse from the main concept. 
Table 3 Loading Factor Value of Extraversion Dimension (Rotated Component Matrix)

\begin{tabular}{|c|c|c|c|c|c|c|}
\hline \multirow[t]{2}{*}{ No. } & \multirow[t]{2}{*}{ Statements } & \multicolumn{5}{|c|}{ Component } \\
\hline & & $\mathbf{1}$ & 2 & 3 & 4 & 5 \\
\hline 1. & I am individual who is easy to adjust & & .422 & & & \\
\hline 2. & I like to be the center of attention & & .445 & & & \\
\hline 3. & I am the type of person who likes to converse & & .513 & & & \\
\hline 4. & I am the type of person who likes to hang out & & .498 & & & \\
\hline 5. & $\begin{array}{l}\text { In many situations I always start a } \\
\text { conversation with others }\end{array}$ & & .697 & & & \\
\hline 6. & $\begin{array}{l}\text { I often dilute the atmosphere of conversation } \\
\text { that is stiff and tense }\end{array}$ & & .742 & & & \\
\hline 7. & I am a person who likes to be merry & & 670 & & & \\
\hline 8. & I am easy to tell what I feel to others & & .465 & & & \\
\hline 9. & I am a assertive person & & .676 & & & \\
\hline 10. & I am the type of rigid person & & .655 & & & \\
\hline 11. & I am the type of shy person & & .737 & & & \\
\hline 12. & I am the type of reticent person & & 690 & & & \\
\hline 13. & $\begin{array}{l}\text { I am the type of person who prefers to be } \\
\text { alone }\end{array}$ & & .574 & & & \\
\hline 14. & I often speak in angry tone & & 677 & & & \\
\hline 15. & $\begin{array}{l}\text { I often get carried away by the atmosphere } \\
\text { around me }\end{array}$ & & .699 & & & \\
\hline 16. & I am the type of morose person & & .596 & & & \\
\hline 17. & I feel that I am a closed person & & .433 & & & \\
\hline 18. & $\begin{array}{l}\text { I prefer to harbor feelings (such as angry, } \\
\text { love, etc) than express spontaneously }\end{array}$ & & .523 & & & \\
\hline
\end{tabular}

\section{Agreeableness Dimension}

Based on the results shown in table 4, twelve of 16 items of question that are expected to form Agreeableness dimension has loading factor $\geq .400$. Six of 8 items of question that use reverse score (reverse score symbolized by the mark ${ }^{\circledR}$ ) also has good loading factor, which the value is more than .400. The items of question were given reverse score reflect the personality type that is reverse from the main concept..

Table 4 Loading Factor value of Agreeableness (Rotated Component Matrix)

\begin{tabular}{|c|c|c|c|c|c|}
\hline \multirow{2}{*}{ No. } & \multirow{2}{*}{ Questions } & \multicolumn{4}{|c|}{ Component/Factor } \\
\hline & & 12 & 3 & 4 & 5 \\
\hline 1. & I always look what it is & & .699 & & \\
\hline 2. & $\begin{array}{l}\text { I am the type of person who cares about other } \\
\text { people's problems }\end{array}$ & & .682 & & \\
\hline 3. & $\begin{array}{l}\text { I am easily to feel what experienced by other } \\
\text { people }\end{array}$ & & .415 & & \\
\hline 4. & $\begin{array}{l}\text { I am always tolerant of other people's } \\
\text { mistakes on me }\end{array}$ & & .384 & & \\
\hline 5. & $\begin{array}{l}\text { I always take the possitives from other } \\
\text { people's actions }\end{array}$ & & .209 & & \\
\hline 6. & I am a person who easily forgive & & .691 & & \\
\hline 7. & I do not like to complain discomfort that I feel & & .734 & & \\
\hline
\end{tabular}




\begin{tabular}{|c|c|c|c|c|c|c|}
\hline \multirow{2}{*}{ No. } & \multirow{2}{*}{ Questions } & \multicolumn{5}{|c|}{ Component/Factor } \\
\hline & & 1 & 2 & 3 & 4 & 5 \\
\hline 8. & I easily make friends with anybody & & & .664 & & \\
\hline 9. & I always try to cover my weakness & & & .685 & & \\
\hline 10. & I am the type of indifferent person & & & .562 & & \\
\hline 11. & I am the type of person who is not responsive & & & 618 & & \\
\hline 12. & I am the type of selfish person & & & .390 & & \\
\hline 13. & I often prejudiced & & & -.150 & & \\
\hline 14. & $\begin{array}{l}\text { I always remember the bad action of others to } \\
\text { me, and if there is a chance I will avenge }\end{array}$ & & & .560 & & \\
\hline 15. & $\begin{array}{l}\text { I often complain that the problems I face } \\
\text { become lighter }\end{array}$ & & & .609 & & \\
\hline 16. & $\begin{array}{l}\text { I do not easily make friends with new people I } \\
\text { know and people who I believe have not been } \\
\text { fully }\end{array}$ & & & .574 & & \\
\hline
\end{tabular}

\section{Openness to Experience Dimension}

Based on the results shown in table 5, fifteen of 18 items of question that are expected to form Openness to Experience dimension has loading factor $\geq .400$. Eight of 9 items of question that use reverse score (reverse score symbolized by the mark () also has good loading factor, which the value is more than .400. However, one item of reverse score remains disposed despite having loading factor 0.631 . This item was discarded because it is a negative question of item that has loading factor of less than 0.4 .

Table 5 Loading Factor Value of Openness to Experiences Dimension (Rotated Component Matrix)

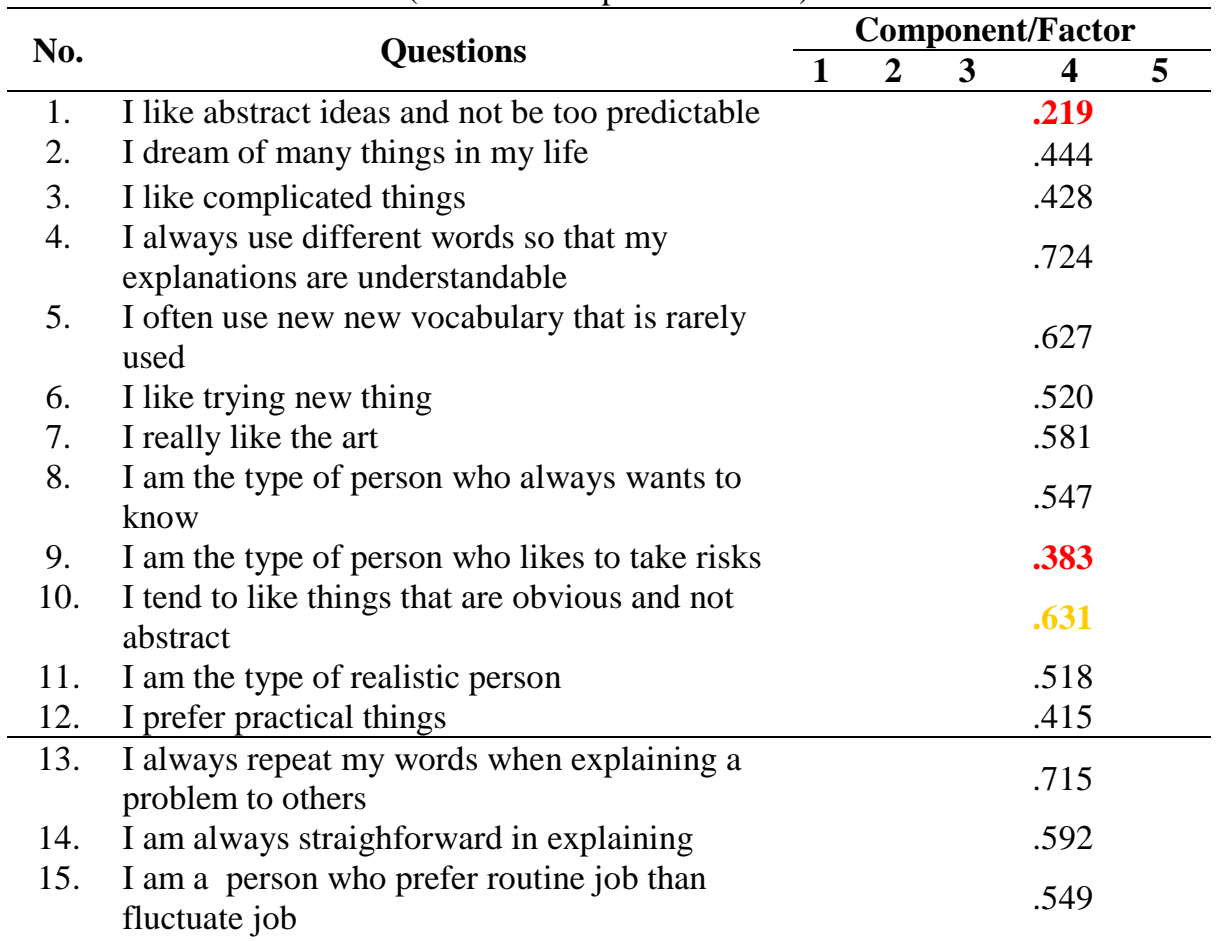




\begin{tabular}{|c|c|c|c|c|c|c|}
\hline \multirow{2}{*}{ No. } & \multirow{2}{*}{ Questions } & \multicolumn{5}{|c|}{ Component/Factor } \\
\hline & & 1 & 2 & 3 & 4 & 5 \\
\hline 16. & I do not occupy a specific hobby & & & & .595 & \\
\hline 17. & $\begin{array}{l}\text { I am the type of person who is not interested } \\
\text { in things outside my job }\end{array}$ & & & & .474 & \\
\hline 18. & $\begin{array}{l}\text { I am the type of person who tries to avoid } \\
\text { risky things }\end{array}$ & & & & .207 & \\
\hline
\end{tabular}

\section{Emotional Stability Dimension}

As shown in table 6, twelve of 14 items of question that are expected to form Openness to Experience dimension has loading factor $\geq .400$. one of 7 items of question that use reverse score (reverse score symbolized by the mark ${ }^{\circledR}$ ) also has good loading factor, which the value is more than 400 .

Table 6 Loading Factor Value of Emotional Stability Dimension (Rotated Component Matrix)

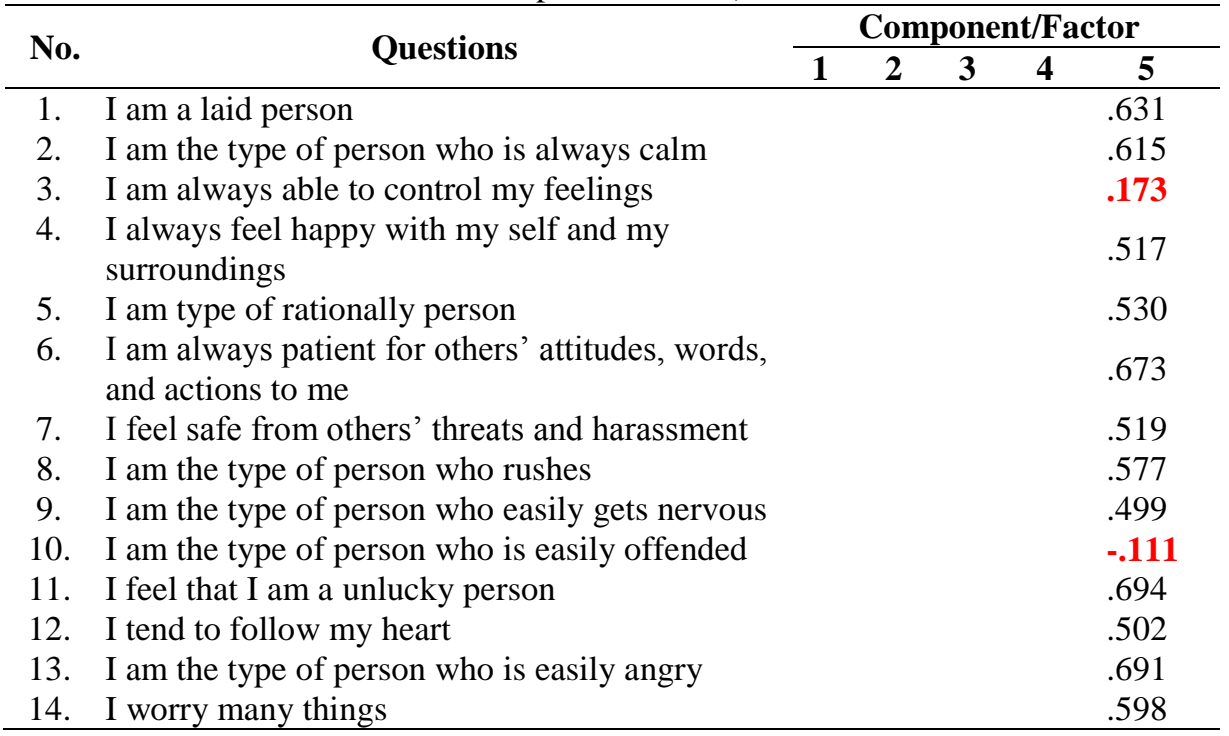

\section{Reliability and Descriptive Statistics}

Means, standard deviation, and Cronbach's Coefficient Alpha of FFM dimension shown in table 7 . With number of the same item for each variable of Conscientiousness and Extraversion dimension, the comparison between dimensions be much easier. Mean value for the Conscientiousness dimension is 69.85 (with standard deviation is 12.280) is higher than mean of Extraversion dimension (with standard deviasion is 12.349). Mean value for Agreeableness dimension is 44.30 (with standard deviasion is 8.161) higher than mean of Emotional Stability dimension namely 39.93 (with standard deviation is 8.707). These three dimensions are the best overall score. It means, overall, mean of respondents for dimensions of FFM in this research had relatively high Conscientiousness scores. Similary, for Emotional Stability and Openness to Experience dimension, is in ithe range of high-to-very high. 
Table 7 Means, Standard Deviations, and Cronbach's Alpha of Five-Factor Dimension

\begin{tabular}{clcccc}
\hline No. & \multicolumn{1}{c}{ Dimensions } & $\begin{array}{c}\text { Number } \\
\text { of Item }\end{array}$ & Means & $\begin{array}{c}\text { Standard } \\
\text { Deviations }\end{array}$ & $\begin{array}{c}\text { Cronbach's } \\
\text { Aplha }\end{array}$ \\
\hline 1. & Conscintiousness & 18 & 69.85 & 12.280 & .918 \\
2. & Extraversion-Intraversion & 18 & 64.23 & 12.349 & .912 \\
3. & Agreeableness & 12 & 44.30 & 8.161 & .887 \\
4. & Openess to Experience & 14 & 49.68 & 7.527 & .845 \\
5. & Emotional Stability & 12 & 39.93 & 8.707 & .875 \\
\hline
\end{tabular}

Table 7 also shows Cronbach's Coefficient Alpha. All dimensions which were produced FFM variable in this research have good level of reliability. This meant that level of inconsistency or unfamiliarity of respondents to the items of question tend low or included in acceptable category. So the items of question were tested in this research was very feasible in measuring FFM dimension, in accordance with the original concept discussed and proven in pervious empirical researchs (Weaven et al., 2009; Gill dan Hodgkinson, 2007; Salgado, 1997; Judge et al., 1998; Fergusen, 2004; Judge dan Erez, 2007; Furnham et al., 2005; Foldes et al., 2008; Marcus et al., 2007).

\section{DISCUSSION}

There were 9 of 84 items of predictabel question capable of measuring the dimensions of FFM, did not produce required loading factor value. 9 these items of question are 4 items for Agreeableness dimension, 3 items of question for Openness to Experience dimension, and 2 items for Emotional Stability dimension. In addition to 9 items above, there is one item of question for Openness to Experience dimension which also rejected despite having loading factor more than 0.4 . The rejection was based on consideration that score of couple item for these items were less than 0.4 , so it was rejected. Ten items were rejected because it did not meet the desired requirements were presentd in table 8 .

For Agreeableness dimension, deleted items of question were: "I am always tolerant of other people's mistakes on me, I always take the possitives from other people's actions, I am the type of selfish person, I often prejudiced". 4 these questions represented two personality traits, namely toleran-selfish and postivenegative. Two these characteristics was originally thought to be most representative of this dimension, but it did not meet the requested loading factor requirement. The explanation that could be given for the rejection to the first nature is that the items of question may be considered unrealistic for now. Excessive tolerant nature may be considered to reflect weakness while the selfish nature tends to be not favored. The second nature, the positive-negative thinking did not meet requesite of loading factor may be due to this nature was considered too directly on the issue. Respondents were hesitant to admit that he/she was a tolerant or selfish and positive or negative thinking.

At the fourth factor/component, namely Openness to Experience dimension, deleted items of question are: "I like abstract ideas and not be too predictable, I am the type of person who likes to take risks, I tend to like things that are obvious and 
not abstract, I am the type of person who tries to avoid risky things". 4 these items reflected the views and interest of a person to something abstract and risky. Two these natures were originally considered to represent this dimension, but it did not meet the requested loading factor requirement. The explanation that can be given for the rejection of the first nature is that the items of question may be considered to be a personality trait which tend to be negative and is something unusual. Background of the community which this research was conducted may be assumed that someone who is not abstract precisely got a good place because it was not considered manipulative, dishonest, and not like the preamble. The rejection of nature that relate with the risk may be caused by the attitude of "middle" which is preferred by the public, including this research's respondents. In indonesia, the nature which is too take the risk regarded as speculative, while attitude which is too avoid the risk regarded impossible.

Table 8 Items of question that do not meet the requirements of Factor Loading value

\begin{tabular}{|c|c|c|c|c|c|c|}
\hline \multirow{2}{*}{ No. } & \multirow{2}{*}{ Questions } & \multicolumn{5}{|c|}{ Component/Factor } \\
\hline & & 1 & 2 & 3 & 4 & 5 \\
\hline 1. & $\begin{array}{l}\text { I am always tolerant of other people's } \\
\text { mistakes on me }\end{array}$ & & & .384 & & \\
\hline 2. & $\begin{array}{l}\text { I always take the possitives from other } \\
\text { people's actions }\end{array}$ & & & .209 & & \\
\hline 3. & I am the type of selfish person & & & .390 & & \\
\hline 4. & I often prejudiced & & & -.150 & & \\
\hline 5. & $\begin{array}{l}\text { I like abstract ideas and not be too } \\
\text { predictable }\end{array}$ & & & & .219 & \\
\hline 6. & $\begin{array}{l}\text { I am the type of person who likes to take } \\
\text { risks }\end{array}$ & & & & .383 & \\
\hline 7. & $\begin{array}{l}\text { I tend to like things that are obvious and } \\
\text { not abstract }\end{array}$ & & & & .631 & \\
\hline 8. & $\begin{array}{l}\text { I am the type of person who tries to avoid } \\
\text { risky things }\end{array}$ & & & & .207 & \\
\hline 9. & I am always able to control my feelings & & & & & .173 \\
\hline 10. & $\begin{array}{l}\text { I am the type of person who is easily } \\
\text { offended }\end{array}$ & & & & & -.111 \\
\hline
\end{tabular}

Two question items of Emotional Stability dimension, which the fifth factor/component was rejected because it had insufficient loading factor value. Two items of question that were expected to help forming these dimensions did not meet the requirements of desired loading factor value, namely question: I am always able to control my feelings and I am the type of person who is easily offended. Two items of this question essentially measures a person's ability and inability to control the feelings. The nature based on respondents' response in this research are not included in Emotional Stability dimension, while conceptually assumed be a major item for this dimension. A possible explanation is given for this result is that the respondents felt very hesitant to identify themselves on the side of feeling control or not control the feelings. The respondents generally felt 
that they were in some situations or for some things can control their feelings well, but for some others were not.

\section{CONCLUSION}

This research concluded that the conceptualization of FFM which consist of five main dimensions of personality, has met the requirements of construct validity. The test results of factor analysis produced five dimension of personality, in a row based on the percentage of data variance which was capable explained: conscientiousness (18 items), extraversion-introversion (18 items), agreeableness (12 items), openness to experience (14 items), and emotional stability (12 items). In addition, this five dimensions of FFM also have good level of reliability.

This research provides the strong support for the conceptualization of the dimensions of FFM, so that the items of measurement can be considered more workable to be used in practical purposes such as employee selection, training and development, promotion, and other practices of Human Resources Management (HRM). The practitioner of organizations, particularly HRM practitioners are advised to use the conceptualization and measurements that have been empirically proven to improve the fit among employees with job/profession that they run.

Future research also needs to clarify the influence of the FFM dimension on the performance of employees, especially in Indonesia. Therefore, should be conducted a research involving respondents from various professions to infer between the personality dimension score with job/profession that they run.

\section{References}

Burke, L.A., \& Witt, L. A. (2004). Personality and High-Maintenance Employee Behavior. Journal of Business and Psychology, 18 (3), 349-363

Costa, P. T., McCrae, R. R. (1992). The NEO-PI Personality Inventory, Odessa, FL: Psychological Assessment Resources.

Elanain, H. M. A. (2007). The Five-Factor Model of Personality and Organizational Citizenship Behavior in United Arab Emirates. S.A.M. Advanced Management Journal, 72 (3), 47-57

Ferguson, E. (2004). Conscientiousness, Emotional Stability, Perceived Control and The Frequency, Recency, Rate and Years of Blood Donor Behavior. British Journal of Health Psychology, 9, 293-314.

Foldes, H.J., Duehr, E.E., \& Ones, D.S. (2008). Group Differences in Personality: Meta-analyses Comparing Five U.S. Racial Groups. Personnel Psychology, 61(3), 579-616.

Friedman, M., \& Rosenman, R.H. (1974). Type A Behavior and Your Heart. New York: Knopf.

Furnham, A., Petrides, K.V., Tsaosis, I., Pappas, K., \& Garrod, D. (2005). A CrossCultural Investigation into The Relationships Between Personality Traits and Work Values. The Journal of Psychology, 139(1), 5-32.

Gill, C.M., \& Hodgkinson, G.P. (2007). Development and Validation of The FiveFactor Model Questionnaire (FFMQ): An Adjectival-based Personality 
Inventory For Use in Accupational Settings. Personnel Psychology, 60(3), 731-766.

Greenberg, J., \& Baron, R.A. (2000). Behavior in Organization: Understanding and Managing the Human Side of Work. New Jersey: Prentice Hall International.

Guthrie, J. P., Ash, R. A., \& Bandapudi, P. (1995). Additional Validity Evidence For a Measure of Morningness. Journal of Applied Psychology, 78, 184193.

Hair, Jr.J.F., Aderson, R.E., Tatham, R.L., \& Black, W.C. (1998). Multivariate Data Analysis. United States: Prentice-Hall International, Inc.

Isen, A.M., \& Baron, R.A. (1992). Positive Affect as a Factor in Organizational Behavior. In B. M. Staw \& L. L. Cummings, eds. Research in Organizational Behavior, 13, 1-54. Greenwich, CT. JAI Press.

Judge, T.A., \& Erez, A. (2007). Interaction and Intersection: The Constellation of Emotional Stability and Extraversion in Predicting Performance. Personnel Psychology, 60(3), 573-596.

Judge, T.A., Martocchio, J.J., \& Thoresn, C.J. (1998). Five-factor Model of Personality and Employee Absence. Journal of Applied Psychology, 82, 745-755.

Juhasz, G., Chase, D., Pegg, E., Downey, D., Toth, Z.G., Stones, K., Platt, H., Mekli, K., Payton, A., Anderson, I. M., \& Deakin, J. F. W. (2009). CNRI Gene is Associated With High Neuroticism and Agreeableness and Interacts With Recent Negative Life Events to Predict Current Depressive Symptoms. Neuropsychopharmacology, 34, 2019-2027.

Marcus, D., Lee, K., \& Ashton, M.C. (2007). Personality Dimensions Explaining Relationships Between Integrity Test and Counterproductive Behavior: Big Five, or One in Addition?. Personnel Psychology, 60, 1-34.

Mount, K., Barrick, M.R., Scullen, S.M., \& Rounds, J. (2005). Higher-order Dimensions of The Big Five Personality and The Big Six Vocational Interest Type. Personnel Psychology, 58(2), 447-478.

Robbins, S.P., \& Judge, T.A. (2009). Organizational Behavior. Pearson Education, Inc. Upper Saddle River, New Jersey.

Salekin, R.T., Leistico, A.R., Trobst, K.K., Schrum, C.L., \& Lochman, J.E. (2005). Adolescent Psychopathy and Personality Theory-the Interpersonal Circumplex: Expanding Evidence of a Nomological Net. Journal of Abnormal Child Psychology, 33(4), 445-460.

Salgado, J.F. (1997). The Five-factor Model of Personality and Job Performance in The European Community. Journal of Applied Psychology, 82, 30-43.

Saucier, G., \& Ostedorf, F. (1999). Hierarchical Subcomponents of The Big Five Personality Factors: A Cross-language Replication. Journal of Personality and Social Psychology, 76(4), 613-627.

Sekaran, U. (2000). Research Methods for Business: A Skill-Building Approach. United Staed of America: John Willey \& Sons, Inc.

Weaven, S., Grace, D., \& Manning, M. (2009). Franchisee personality An examination in the context of franchise unit density and service classification. European Journal of Marketing, 43(1/2), 90-109. 